\title{
Nutrient Export with Logs, and Release from Residues, after Harvest of a Pinus taeda Plantation in Uruguay
}

\author{
Amabelia del Pino, Jorge Henández, Gimena Arrarte \\ Department of Soil Science, Facultad de Agronomía, UDELAR, Montevideo, Uruguay \\ Email: amabelia@fagro.edu.uy
}

How to cite this paper: del Pino, A. Henández, J., \& Arrarte, G. (2020). Nutrient Export with Logs, and Release from Residues, after Harvest of a Pinus taeda Plantation in Uruguay. Open Journal of Forestry, 10, 360-376.

https://doi.org/10.4236/ojf.2020.103022

Received: April 20, 2020

Accepted: June 14, 2020

Published: June 17, 2020

Copyright $\odot 2020$ by author(s) and Scientific Research Publishing Inc. This work is licensed under the Creative Commons Attribution International License (CC BY 4.0).

http://creativecommons.org/licenses/by/4.0/

\begin{abstract}
In Uruguay, Pinus taeda is usually planted a few months after harvest of the former turn, therefore; decomposing residues represents a nutrient source for the new plantation. The aim of this study was to determine the biomass and nutrient extraction off site, following the harvest of a $P$. taeda plantation. Residue decomposition patterns, and nutrient release were also examined. The site will be referred as S1, corresponding to the clear cut of a 22-year-old $P$. taeda plantation. Before the clear cut 10 trees were harvested, and logs, branches, twigs, and needles separately weighed. Additionally, forest litter at harvest time was quantified in three different areas. To assess decomposition, mesh bags with residues were allocated in three areas over the forest litter, and samples were taken periodically for 26 months. The remaining biomass, $\mathrm{N}, \mathrm{P} \mathrm{K}, \mathrm{Ca}$, and $\mathrm{Mg}$ contents were determined in the different fractions, calculating decompositon rates. Most of the harvested biomass was removed in logs, but the proportion of nutrients exported was considerably lower. Needles showed the highest biomass loss and only 39.1\% remained after 26 months, while branches presented high rates in the first two months after cut, but slower thereafter, and at the end of the study more than two thirds of the woody residues remained. Potassium was rapidly released from the residues, while $\mathrm{Ca}$, and $\mathrm{Mg}$, were slowly released, and there was evidence of $\mathrm{N}$ and $\mathrm{P}$ immobilization in the early stages of decomposition. It was concluded that, although a lower proportion of nutrients were exported, compared to biomass, in the long term, nutrient export with logs could be significant for the sustainability of this production system. While $\mathrm{K}$ release from residues did not depend on biomass decay, the slow decomposition, and release of the other nutrients, indicates that this process could have been delayed by nutrient scarcity.
\end{abstract}




\section{Keywords}

Residue Decomposition, Litter Bags, Litter Quality, Nutrient Cycling

\section{Introduction}

Forest production in Uruguay has significantly increased in the last three decades, and the area covered by forests has been multiplied several times. At present, many of the plantations correspond to second or third turn; therefore, the harvest residue management takes special meaning in order to minimize environmental hazards and make efficient use of the nutrients within the residues. However, the knowledge of the best residue management practices, and the potential cycling of the nutrients after harvest, is still scarce. To make the best use of the land, the following turn of Pinus taeda is usually planted just a few months after clear cut, with minimum fertilizer application. In consequence harvest residue decomposition accompanies the growth of the new plantation, and the decomposed material is expected to release nutrients to the growing trees (Tutua et al., 2008; Turner \& Lambert, 2013; Mavimbela et al., 2018).

After tree harvest, the exportation of nutrients with logs, and the pace of residue decomposition on site, are likely to alter the soil carbon and nutrient balances (Ruiz-Peinado et al., 2013; Bravo-Oviedo et al., 2017). The nutrient export with logs depends largely on the volume of wood harvested (Goya et al., 2003; Ghaffariyan \& Apolit, 2015), but local characteristics, like soil type and climate, determine the availability of nutrients in the remaining residues (Jones et al., 1999). Jobbagy \& Jackson (2003), studying the effect of afforestation in soils of Argentina concluded that the extraction, recycling and re-distribution of cations promoted by the trees is the main mechanism of soil acidification in this production system. In New Zealand Parfitt et al. (1997) observed a decrease in soil C and $\mathrm{N}$, concomitant with the soil acidification in 20-year-old $P$. radiata plantations. In their work increases of $\mathrm{Ca}, \mathrm{Mg}$ and $\mathrm{K}$ content of the upper soil layer was observed, which they attributed to recycling of the cations from deep soil layers, through the forest litter. Consequently, to characterize the nutrient cycling in the forest is a key step to assess the sustainability of this production system.

To ensure the reutilization of the nutrients in residues, many distinct factors, concerning forest residue management and decomposition, justify a closer examination. One of the most important of these factors is that, unlikely other cultures, forest residues remain over the soil surface, without further incorporation, and are only slowly integrated to the soil (Pérez-Batallón et al., 2001). The physical condition of forest harvest residues is also different from most crop residues, because many of them are large-sized, and this reduces their degradability (Garret et al., 2007; Shorohova et al., 2016). Another especial characteristic is the low nutrient concentrations observed in the woody residues (branches 
and bark). This fact, together with the high content of lignin, resistant to degradation, and the low content of soluble organic substances, which promote degradation, offers an inadequate environment for the development of decomposing organisms (Berg \& McClaugherty, 1989; Bani et al., 2018). In addition to the characteristics of the residues, there are other factors influencing the decomposition process, especially related to climatic conditions. Both temperature and humidity directly affect the residue degradation and the growth of decomposers (Dalias et al., 2001). It is expected therefore that decomposition rates would be higher in summer, especially if rainfall is abundant, although it has been found that these fluctuations loose significance in the long term (Prescott, 2005). The knowledge of the decomposition patterns of forest residues, and the factors affecting nutrient release, enables the improvement of residue management practices with the aim to optimize nutrient use (Jones et al., 1999; Tutua et al., 2008; Segura et al., 2017). This knowledge will also provide useful information to test the sustainability of these production systems, and to predict the fertilizer and amendment needs (Węgiel et al., 2018).

The objective of this work was to assess the nutrient export of a Pinus taeda $\mathrm{L}$. plantation, and the potential for nutrient return to the soil. We also studied decomposition of $P$. taeda residues in the field and the patterns of nutrient release.

\section{Materials and Methods}

The experiment was located in Rivera, Uruguay (coordinates: $31^{\circ} 11^{\prime} 33.4^{\prime \prime S}$ and $\left.55^{\circ} 39^{\prime} 08.4^{\prime \prime} \mathrm{W}\right)$. This region has a mean annual temperature of $18.1^{\circ} \mathrm{C}$, a mean temperature of $12.3^{\circ} \mathrm{C}$ in the coldest month (June) and $24.1^{\circ} \mathrm{C}$ in the warmest month (January). Average annual rainfall is $1639 \mathrm{~mm}$, without important differences in monthly rainfall, although it is highly irregular (INUMET, 2020).

The studied site (S1) corresponded to the clear cut of a 22-year-old Pinus taeda stand, with a plantation density of 200 trees $\cdot \mathrm{ha}^{-1}$. The soil (Table 1 ) was a fine, mixed, semiactive, thermic typic hapludult (Soil Survey Staff, 2006).

Before the clear cut 10 trees, with average height and diameter, were harvested to estimate biomass production and nutrient export with logs. The harvest date was March 07, 2006. Immediately after cut the trees were separated into: commercial and noncommercial logs (diameter less than $20 \mathrm{~cm}$ ), branches with diameter between 1 and $2 \mathrm{~cm}$, twigs and needles, which were separately weighed. Five disks ( $3 \mathrm{~cm}$ high) were cut from the logs (stem with bark) for dry matter calculation. In $\mathrm{S} 1$ the forest litter (mainly composed by fine branches and needles) was assessed, collecting all the material that could be separated from the mineral soil in 5 different areas $\left(1 \mathrm{~m}^{2}\right.$ each).

Residue decomposition was studied using litter bags, that were prepared immediately after harvest in the plantation, and let to decompose over the forest litter. From each of the fine fractions (needles and twigs) $100 \mathrm{~g}$ of material was placed into mesh bags. The branches were cut into pieces (approximately $10 \mathrm{~cm}$ length) and individually weighed and labelled. Additionally, bags were filled with $100 \mathrm{~g}$ of forest floor litter. Enough litter bags and branches were prepared to 
Table 1. Chemical characteristics of the soil.

\begin{tabular}{cccccccc}
\hline & & \multicolumn{5}{c}{ Exchangeable cations } \\
\hline Depth & $\mathrm{OM}$ & $\mathrm{pH}$ & $\mathrm{Ca}$ & $\mathrm{Mg}$ & $\mathrm{K}$ & $\mathrm{Na}$ & $\mathrm{Al}$ \\
\hline $\mathrm{cm}$ & $\%$ & & & \multicolumn{5}{c}{$\mathrm{cmol}_{\mathrm{c}} \cdot \mathrm{kg}^{-1}$} \\
\hline $0-18$ & 1.31 & 4.45 & 0.67 & 0.19 & 0.13 & 0.41 & 0.85 \\
$18-40$ & 0.89 & 4.50 & 0.50 & 0.08 & 0.10 & 0.41 & 1.12 \\
$40-80$ & 0.32 & 4.55 & 0.50 & 0.15 & 0.09 & 0.46 & 1.56 \\
$80-120$ & 0.40 & 4.60 & 1.00 & 0.46 & 0.16 & 0.40 & 2.89 \\
\hline
\end{tabular}

allow sampling along the two-year study. A group of litter bags and branches was replicated in three different areas in the field, and each group was covered with a wire mesh to avoid damages by birds and other animals. Samples of each tree component (commercial and noncommercial logs, branches, twigs, needles, and forest litter) were collected at harvest for analysis. During the decomposition experiment three litter bags per fraction, and 6 samples of branches, were collected at 2, 4, 6, 12, 18 and 26 months. The residues were allocated to the three areas on March 07, 2006, and the last sampling was at May 28, 2008. During the residue decomposition experiment, temperature at the soil surface and rainfall were recorded (Figure 1). Due to failures in the temperature recording equipment, data is not available for certain periods.

The collected residue samples, and those belonging to the decomposition experiment, were dried at $60^{\circ} \mathrm{C}$, ground to pass a $0.5 \mathrm{~mm}$ mesh, and total contents of $\mathrm{N}, \mathrm{P}, \mathrm{K}, \mathrm{Ca}$ and $\mathrm{Mg}$ were determined. For $\mathrm{N}$ analysis a modified Kjeldahl method was used (Bremner \& Mulvaney, 1982). To determine P, K, Ca and Mg the samples were mineralized in muffle at $550^{\circ} \mathrm{C}$ for 5 hours, and the ashes dissolved in $\mathrm{HCl}$. Contents of $\mathrm{Ca}$ and $\mathrm{Mg}$ were determined by atomic absorption spectrophotometry, and $\mathrm{K}$ was determined by emission spectrophotometry (Isaac \& Kerber, 1971). The same extract was used for P content colorimetrical analysis (Murphy \& Riley, 1962). At four sampling dates residue quality was assessed, analysing lignin, soluble $\mathrm{C}$, and polyphenol in the residues. The lignin content was gravimetrically determined after acid hydrolysis (Pettersen, 1984). The content of polyphenol was extracted with water at $100^{\circ} \mathrm{C}$ for 30 minutes, and later determined using the Folin-Ciocalteau method with a tannic acid standard (Singleton \& Rossi, 1965). In the same extract the soluble $\mathrm{C}$ content was determined by oxidation with $\mathrm{K}_{2} \mathrm{Cr}_{2} \mathrm{O}_{7}$ in concentrated $\mathrm{H}_{2} \mathrm{SO}_{4}$, followed by colorimetric determination (Nelson \& Sommers, 1996).

Decomposition was calculated as percentage of initial biomass from the weight loss of the litter bags and branches. Exponential decay models were fitted to the data: $W_{t}=W_{0} \exp (-k t)$, where $W_{t}$ is remaining biomass at time $t$ in years (as percentage of initial weight), $W_{0}$ is initial biomass and $k$ the decay constant expressed in year $^{-1}$. In view of the particular trends observed in the biomass loss, two models were adjusted: One of them for the first 6 months of decomposition, and the second from the $6^{\text {th }}$ month to the end of the study. In the model fitted for the second period $W_{0}$ was the remaining biomass at the $6^{\text {th }}$ month sampling. 
For the model fitting the NLIN procedure of SAS 9.1 was used (SAS, 2011). The amounts of nutrients in the different fractions were calculated multiplying the biomass by the respective nutrient concentration.

\section{Results and Discussion}

\subsection{Biomass Production and Nutrient Export}

The commercial logs represented the largest portion of the harvested biomass, (77\%); while a substantial proportion of residues consisted of branches and noncommercial logs (Table 2 ). In contrast with the woody residues, the needles accounted for only $13 \%$ of the harvested biomass. Additionally, the quantified forest litter accounted for $13 \mathrm{Mg} \cdot \mathrm{ha}^{-1}$, that should be added to the biomass left on the site by the plantation.
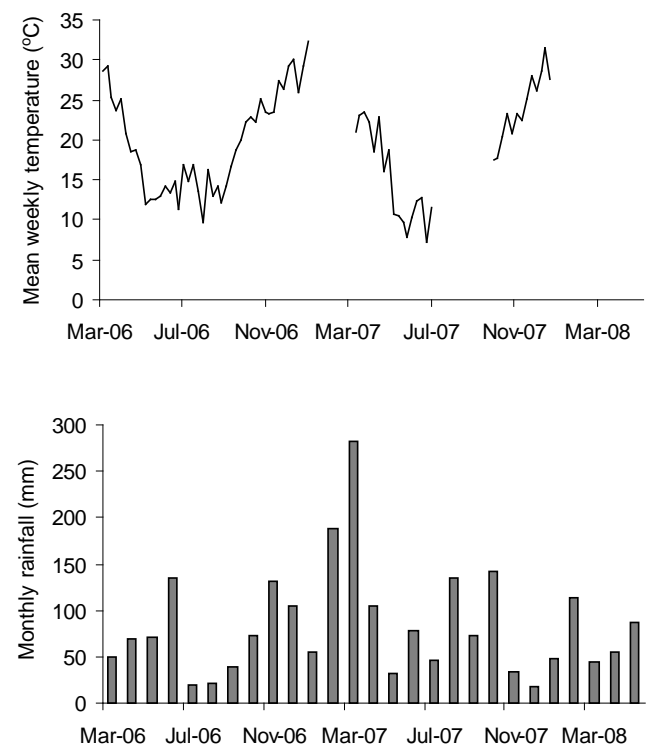

Figure 1. Time course of temperature at the soil surface (weekly average) and rainfall (accumulated amount per month) during the harvest residue decomposition study.

Table 2. Aerial biomass, nutrient content, and nutrient concentration in logs and harvest residues of a 22-year-old $P$. taeda plantation. Average of 10 trees, standard deviation between parenthesis.

\begin{tabular}{|c|c|c|c|c|c|c|c|c|c|c|c|}
\hline & \multicolumn{6}{|c|}{ Nutrient content } & \multicolumn{5}{|c|}{ Nutrient concentration } \\
\hline & Biomass & $\mathrm{N}$ & $\mathrm{P}$ & K & $\mathrm{Ca}$ & $\mathrm{Mg}$ & $\mathrm{N}$ & $\mathrm{P}$ & K & $\mathrm{Ca}$ & $\mathrm{Mg}$ \\
\hline & $\mathrm{Mg} \cdot \mathrm{ha}^{-1}$ & & & $\mathrm{~kg} \cdot \mathrm{ha}^{-1}$ & & & & & $\mathrm{~g} \cdot \mathrm{kg}^{-1}$ & & \\
\hline Logs & $190(13)$ & $157(62)$ & $31(5)$ & $56(16)$ & $106(26)$ & $35(8)$ & 0.83 & 0.16 & 0.29 & 0.56 & 0.18 \\
\hline Branches and $n / c$ logs & $48(12)$ & $206(71)$ & $17(4)$ & $93(37)$ & 149 (39) & $28(8)$ & $5.00^{*}$ & $0.29^{*}$ & $2.21^{*}$ & $2.53^{\star}$ & $0.61^{*}$ \\
\hline Needles & $9(2)$ & $97(20)$ & $8(2)$ & $45(13)$ & $16(7)$ & $7(2)$ & 10.78 & 0.89 & 5.00 & 1.78 & 0.78 \\
\hline Total residue & $57(14)$ & $303(90)$ & $25(5)$ & $137(41)$ & $166(43)$ & $35(9)$ & & & & & \\
\hline Total biomass & $246(24)$ & $460(130)$ & $56(9)$ & $194(49)$ & $272(53)$ & $70(14)$ & & & & & \\
\hline Export with logs (\%) & 77 & 34 & 55 & 29 & 39 & 50 & & & & & \\
\hline
\end{tabular}

${ }^{\star}$ Average content of noncommercial logs, branches and twigs. 
After cut most of the nutrients within the trees remained in the residues, although they were not the majority of the aerial biomass, and this can be attributed to the lower nutrient concentrations of logs, compared to the other fractions. It should be noticed that in $P$. taeda plantations in Uruguay de-barking is made off-site, and this is likely to increase the nutrient export (Goya et al., 2003). Clear cut residues, in consequence, could represent an important source of nutrients for the following turn, if they are adequately managed (Ouro et al., 2001; Tutua et al., 2008; Mavimbela et al., 2018).

Nitrogen and $\mathrm{Ca}$ were the most abundant nutrients in the aerial biomass, while $\mathrm{P}$ accounted for the lowest amount. Regarding the distribution of nutrients in the different fractions, most of them were in woody residues, although needles presented higher concentrations. The low nutrient content of logs is in line with data reported by Laclau et al. (2000), who observed decreasing nutrient content for older trees, and suggests that this 22-year-old forest makes efficient use of nutrients. The highest proportion of exported nutrients corresponded to $\mathrm{P}$ and $\mathrm{Mg}$, while $\mathrm{N}$, $\mathrm{Ca}$ and $\mathrm{K}$ presented rather low extraction ratios, in contrast with biomass extraction. Wegiel et al. (2018), who studied nutrient removal of $P$. sylvestris stands in Poland, in agreement with our results, reported a lower proportion of nutrients in logs, compared to biomass, and found that the highest proportion of exported nutrients corresponded to $\mathrm{Mg}$.

There are no previous studies regarding nutrient extraction of pine forests in Uruguay; therefore only international information could be used for comparison. In Argentina Goya et al. (2003) examined the nutrient extraction after clear cut of a 20-year old $P$. taeda unthinned plantation, with a higher biomass yield than S1 (388.1 Mg.ha ${ }^{-1}$ ). As expected, the amounts of extracted nutrients were higher than those of S1, especially for $\mathrm{N}, \mathrm{Ca}$ and $\mathrm{K}$, but not for $\mathrm{P}$ and $\mathrm{Mg}$, which were similar in both sites. In Spain Ouro et al. (2001) studied a P. radiata plantation, with similar wood production as S1 (180. $\left.\mathrm{Mg} \mathrm{ha}^{-1}\right)$, and found amounts of $\mathrm{N}$ (extracted, exported and remaining in residues) that were remarkably close to those of our work. In their study the amounts of most of the other nutrients (Ca, $\mathrm{Mg}$, and $\mathrm{P}$ ) showed similarities, but the amounts of extracted $\mathrm{K}$ were nearly three times compared to S1, probably due to a higher K supply capacity of the soil. Although per year nutrient absorption by trees represents relatively low amounts, these results highlight the significance of the long-term nutrient extraction from these low fertility sites, that should be taken into account to assess their future productivity.

\subsection{Harvest Residue Decomposition}

The slow pace of forest residue decomposition in temperate climates confirms the necessity to gather information from long term studies. After 26 months of decomposition of $P$. taeda residues in the field, $61 \%$ of the initial biomass was still undecomposed, and the biomass loss of woody residues represented only $30 \%$ (Figure 2). 


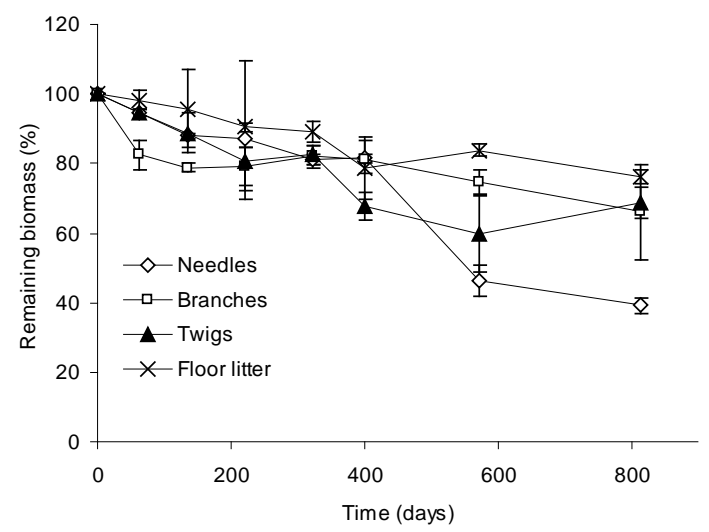

Figure 2. Time course of remaining biomass in harvest residues of a 22 -year-old $P$. taeda plantation (\% of the initial weight). Vertical bars represent standard deviation.

After reviewing previous work (Ouro et al., 2001; Alvarez et al., 2008), we expected faster decomposition of the needles compared to the other fractions, because needles are small-sized, with high nutrient contents, hence they could be easily colonized by decomposers. However, needles had lower decomposition rates than branches at the beginning of the experiment. This fact can be connected to the resistant cuticle (Palviainen et al., 2004) and high polyphenol content of needles, which can hinder the microbial attack (Kraus et al., 2003). Also, climatic factors, that are discussed below, could have contributed to these results. In agreement, when the parameters of the fitted decay models were examined, lower decomposition rates at the beginning of the study were observed in needles (Table 3). The $k$ value for needles was higher in the second period than in the first, while the branches showed the opposite trend. In the second period wide differences were observed, since $k$ was higher for needles than the other fractions, and the decomposition ratio of forest litter was extremely low. This fraction decomposed very slowly, and did not undergo major changes along the study, which can be attributed to the fact that it was partially decomposed at the beginning of the study, and this led to depletion of soluble organic substances, that could promote microbial activity (Bani et al., 2018).

Differences in decomposition patterns of the fractions could be related to residue quality changes along the decay process (Figure 3). Needles and twigs showed high initial polyphenol content, while the lowest corresponded to branches. Along the study the polyphenol content of needles and twigs strongly decreased in the first year after harvest, with a gradual decrease in the following period, reaching a similarly low value as branches. The initial lignin content was similar in the three components $\left(395,388\right.$ y $376 \mathrm{~g} \cdot \mathrm{kg}^{-1}$ for needles, twigs and branches respectively), and decreased in the first three months, especially in branches, while an increase was observed thereafter, probably due to the loss of cellulose and hemicellulose, which are more decomposable. Soluble C concentration of needles was nearly twice the other fractions, and decreased, likewise the polyphenol content; but this trend was less pronounced in the branches and 
twigs, which presented a rather stable low content. It was unexpected that the soluble $\mathrm{C}$ content of needles gradually declined, in opposition to the sharp decline reported by Girisha et al. (2003) during decomposition of radiata pine
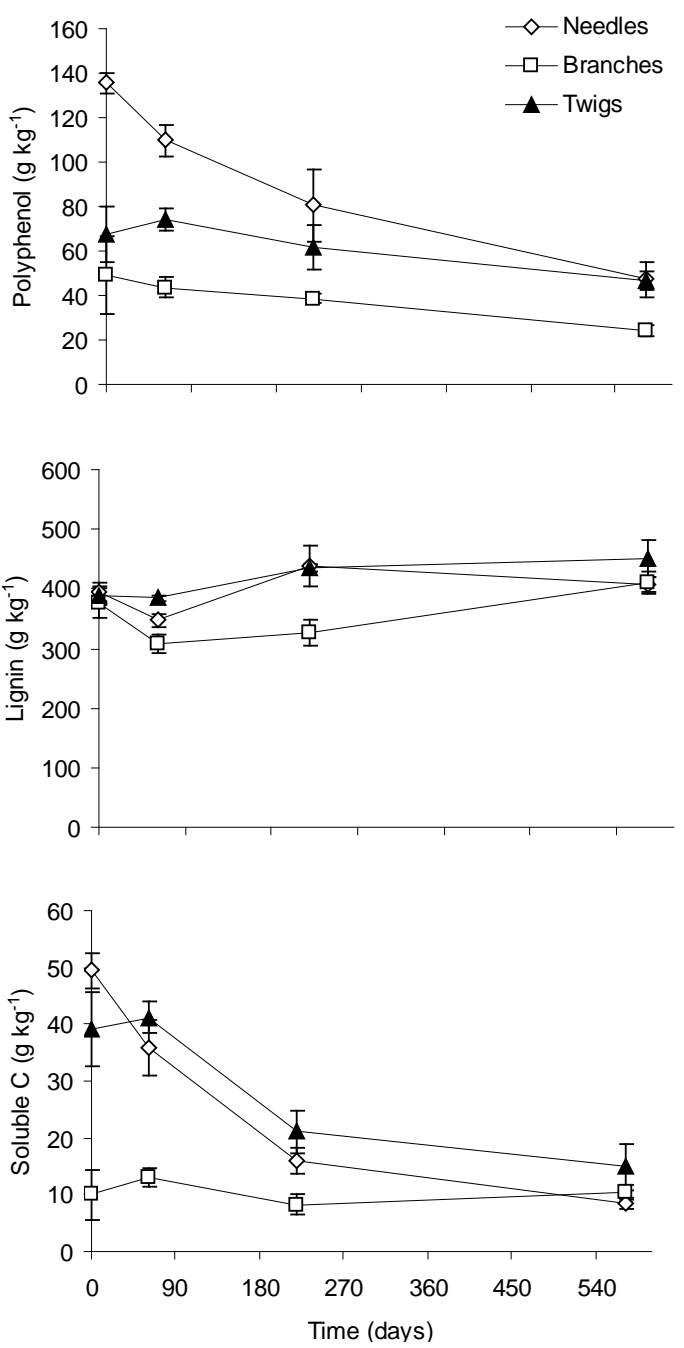

Figure 3. Time course of polyphenol, lignin, and soluble C content in harvest residues of a 22 -year-old $P$. taeda plantation. Vertical bars represent standard deviation.

Table 3. Parameters of the decay model fitted for harvest residues of a 22 -year-old $P$. taeda plantation (\% of the initial weight). The decomposition constant $k_{1}$ corresponds to the first 6 months of decomposition, $k_{2}$ to the period from the $6^{\text {th }}$ month until the end, and $k$ to the whole period under study.

\begin{tabular}{cccccccccc}
\hline & $k_{1}$ & $R^{2}$ & Prob. & $k_{2}$ & $R^{2}$ & Prob. & $k$ & $R^{2}$ & Prob. \\
\hline & year $^{-1}$ & & & year $^{-1}$ & & & year $^{-1}$ & & \\
\hline Needles & 0.25 & 0.77 & $<0.01$ & 0.62 & 0.94 & $<0.01$ & 0.45 & 0.70 & $<0.01$ \\
Branches & 0.46 & 0.74 & $<0.01$ & 0.19 & 0.72 & $<0.01$ & 0.20 & 0.72 & $<0.01$ \\
Twigs & 0.37 & 0.75 & $<0.01$ & 0.13 & 0.85 & $<0.01$ & 0.23 & 0.73 & $<0.01$ \\
Floor litter & 0.17 & 0.77 & $<0.01$ & 0.07 & 0.61 & $<0.01$ & 0.12 & 0.75 & $<0.01$ \\
\hline
\end{tabular}


needles in New Zealand. As discussed, this suggests the presence of a physical barrier to decomposition, because these soluble substances are likely to be the more easily assimilable $\mathrm{C}$ sources for microbial biomass. The acceleration of needle decomposition in the second year in S1 could be caused by the disappearance of the physical constriction, together with a decline in polyphenol content. Goma-Tchimbakala \& Bernhard-Reversat (2006) observed a rapid disappearance of soluble polyphenol during the decomposition of forestry residues, which they associated to increases in decomposition rates. Shortly after harvest the highest biomass losses, and the main source for nutrient release corresponded to branches. This was contrasting with the slow decomposition of twigs, probably due to their high content of soluble polyphenols, that hinder microbial growth (Kraus et al., 2003). However, decomposition rates of branches in the following period were rather low, in line with the literature regarding decomposition of woody residues (Ganjegunte et al., 2004; Hernández et al., 2009; Vávřová et al., 2009). Furthermore, in this study the bark, which is also resistant to decomposition was not separated from the branches, and it is likely to have influenced their decomposition process (Shorohova et al., 2016).

The plantation was harvested at the end of the summer, in consequence the first decomposition period in S1 corresponded to autumn-winter in the Southern Hemisphere. Therefore, it is likely that the interaction between residue quality and environmental factors, observed in many decomposition studies, influenced decomposition patterns (McTiernan et al., 2003; Vávřová et al., 2009; Segura et al., 2017). The fact that in the period following the harvest, in autumn, low temperatures were predominant, could explain the relatively slow decomposition of needles in the initial period (Dalias et al., 2001; Garret et al., 2007), with the opposite trend in the second period, when the rate of biomass loss from needles increased. Since residues were left to decompose over the forest floor, to explain decomposition the photo degradation should be also considered Austin \& Vivanco (2006) observed important effects of sunlight exposure on grass litter decomposition, which they attributed to direct effect of light, especially UV radiation, causing the break down of the organic materials. Likewise, Wu et al., (2018) reported increases in forest residue decomposition by photo degradation, and consequently proposed that light exposure affected microbial communities and their activity.

At the end of the study, a change in decomposition trends of needles and branches, especially in the last two samplings, suggests that after some time in the field the plant structures were weaker, hence more decomposable. It is only possible to speculate if this trend of increasing decomposition speed would ultimately lead to a complete destruction of the material in a shorter term than it is expected from the calculated decomposition rates, as observed by Prescott (2005). Interestingly decomposition studies of eucalyptus harvest residues in Uruguay showed similar trends of late acceleration (Hernández et al., 2009; González et al., 2016; Hernández et al., 2016). It should be noticed that mathematical models 
not always are capable to describe the biological processes. Ganjegunte et al. (2004), who studied decomposition of $P$. radiata coarse woody debris, reported bias from the adjusted models, with higher decomposition than expected in logs and bark, and lower for side branches.

\subsection{Nutrient Release from Residues}

At harvest, and throughout the decomposition process, the nutrient concentrations were higher for needles than any other fraction, except for $\mathrm{Ca}$, which was higher in floor litter and twigs. It should be noticed that nutrient concentration of residues along the decomposition process is the result of biomass loss (mainly C), nutrient release from residues, and even microbial immobilization of soil nutrients (McTiernan et al., 2003; Bowman et al., 2004). These processes in many cases follow divergent directions, with variations throughout the decomposition of the different fractions (Alvarez et al., 2008).

Nitrogen release from residues was scarce, with increases in $\mathrm{N}$ concentration in all fractions, except branches (Figure 4). The increase in $\mathrm{N}$ concentration in residues, especially at the beginning of the study, indicates that the decomposition process promoted $\mathrm{N}$ immobilization (Berg \& McClaugherty, 1989). The initial C:N ratio was 42, 78, 95 and 45 for needles, branches, twigs and floor litter respectively, therefore it could be expected a net $\mathrm{N}$ immobilization during decomposition (Corbeels et al., 2003). The amount of $\mathrm{N}$ in floor litter did not decrease throughout the study, in line with results obtained for floor litter of eucalyptus plantations in Uruguay (Hernández et al., 2009) while branches showed the highest $\mathrm{N}$ losses. An important proportion of the initial $\mathrm{N}(63 \%)$ remaining in the residues at the end of the experiment (Table 4), in coincidence with results reported in other studies, for leaf litter and woody residues (Bowman et al., 2004; Ganjegunte et al., 2004). Nevertheless, it was unexpected to find a higher increase in needle $\mathrm{N}$ concentration than in coarse residues, especially branches, which presented, initial low $\mathrm{N}$ concentrations, and substantially higher C:N ratios. One possible explanation is related to the high soluble $\mathrm{C}$ content of needles, which is readily available for decomposers, and could have increased their $\mathrm{N}$ requirements. These results, together with the fact that $\mathrm{N}$ was the most abundant nutrient in the harvested biomass, suggest that these forests make an efficient use of this nutrient, and recycling plays an important role in maintaining the $\mathrm{N}$ availability for the growing trees. After harvest of hoop pine plantations in Australia, Blumfield \& Xu (2003) reported lower mineral $\mathrm{N}$ losses in the sites where residues were left to decompose compared to the sites where residues were removed, and they attributed this result to a higher $\mathrm{N}$ immobilization in residues. In our experiment the fate of the immobilized $\mathrm{N}$ is unknown, but it can be expected to be slowly released, and therefore available for the second turn plantation. Although soil mineral $\mathrm{N}$ content was not examined, this element is usually scarce in winter, and it is likely that residue decomposition was limited by its availability. 

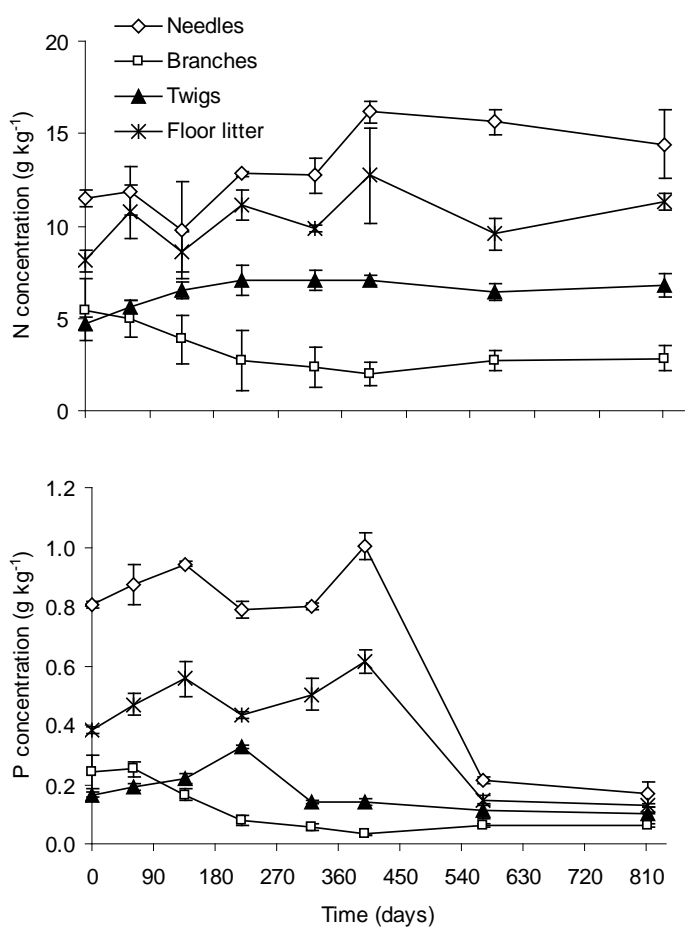

Figure 4. Time course of $\mathrm{N}$ and $\mathrm{P}$ concentration in harvest residues of a 22-year-old $P$. taeda plantation. Vertical bars represent standard deviation.

Table 4. Remaining nutrients in harvest residues of a 22-year-old $P$. taeda plantation. Percentage of the initial amount after 26 months of decomposition.

\begin{tabular}{cccccc}
\hline & N & P & K & Ca & Mg \\
\hline Needles & 43 & 8 & 8 & 61 & 28 \\
Branches & 33 & 11 & 10 & 42 & 41 \\
Twigs & 94 & 42 & 10 & 54 & 55 \\
Floor litter & 104 & 21 & 30 & 55 & 54 \\
\hline
\end{tabular}

There was a decrease in $\mathrm{P}$ concentration of branches in the first months, while it increased in all other fractions, suggesting microbial immobilization (Berg \& McClaugherty, 1989; Bani et al., 2018). Thereafter the fractions did not suffer major changes, presenting stable $\mathrm{P}$ concentrations, but in the last two samplings all fractions showed decreasing $\mathrm{P}$ concentrations. Consequently, the amount of $\mathrm{P}$ remaining in residues at the end of the experiment was only $15 \%$ of the initial stock. It should be noticed that, although the amounts of $\mathrm{P}$ involved in the potential recycling are lower than those of the other nutrients, they could be significant, given the extremely low P supply capacity of the sandy soils of this area (Durán \& García Préchac, 2009).

During the decomposition study, $\mathrm{K}$ concentration of all fractions rapidly decreased, indicating that its loss was not linked to biomass decay (Figure 5). This, 

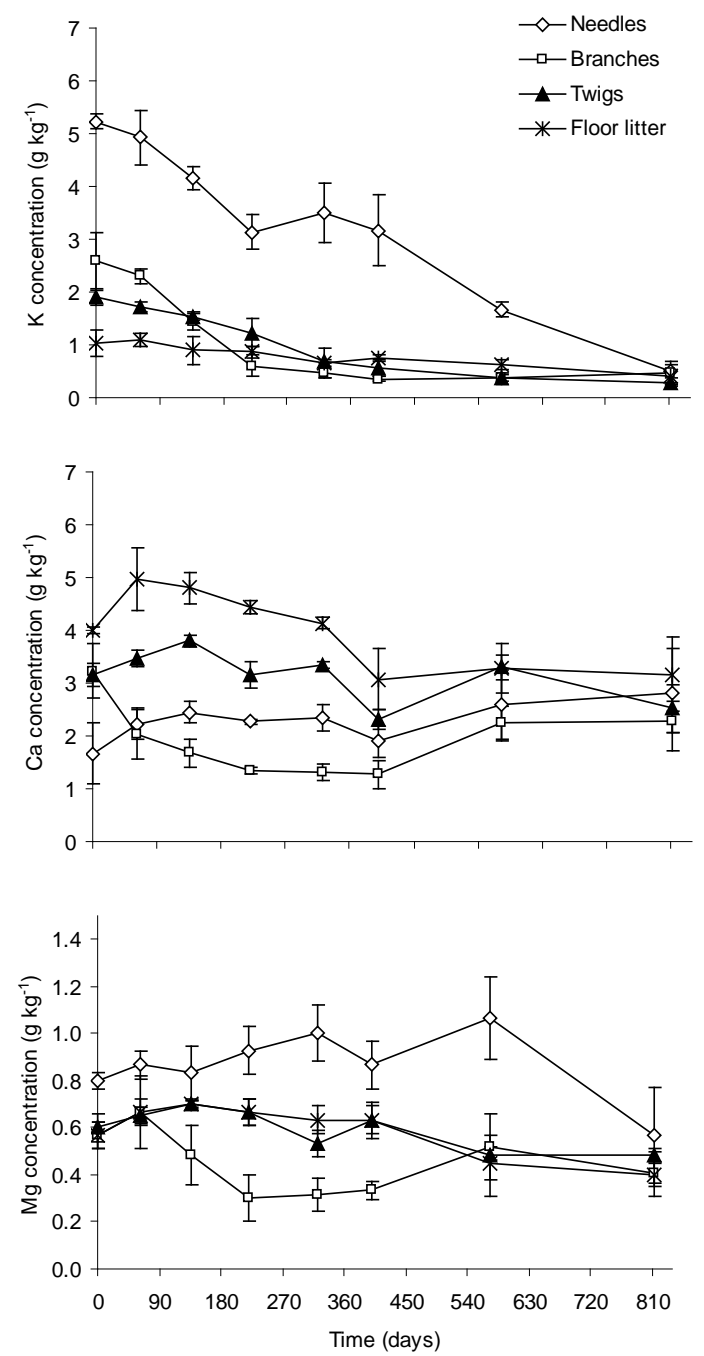

Figure 5. Time course of $\mathrm{K}, \mathrm{Ca}$, and $\mathrm{Mg}$ concentration in harvest residues of a 22-year-old $P$. taeda plantation. Vertical bars represent standard deviation.

together with the biomass loss, nearly caused the depletion of $\mathrm{K}$, because at the end of the study only $12 \%$ of the initial $\mathrm{K}$ remained in the harvest residues. The rapid $\mathrm{K}$ loss is coincident with results obtained in many studies with pine residues (Girisha et al., 2003; Palviainen et al., 2004; Alvarez et al., 2008) and likewise with eucalyptus residues in Uruguay (Hernández et al., 2009; González et al., 2016; Hernández et al., 2016). This could be related to the fact that $\mathrm{K}$ does not form organic compounds; hence it can be easily leached by rainfall in the predominantly humid climate (Jacobs et al., 2009).

In contrast with $\mathrm{K}$ rapid disappearance, $\mathrm{Ca}$ was slowly released, remaining in residues at the end of the experiment almost half of the initial Ca. Moreover, most of the Ca was lost from the branches, which decomposed rapidly in the initial period. In all other fractions $\mathrm{Ca}$ concentration increased in the first year, indicating that decomposition of $\mathrm{Ca}$ rich compounds was slower than biomass degradation, in agreement with data from Girisha et al. (2003) and Alvarez et al. 
(2008). Although Ca plays many roles in plants, the most important is related to cell wall integrity, therefore forming part of recalcitrant structures. Throughout the study, floor litter presented the highest Ca concentration, and branches the lowest, although towards the end of the study $\mathrm{Ca}$ increased in branches, probably due to the acceleration in biomass loss (Shortle et al., 2012; Bani et al., 2018).

Magnesium concentration in all fractions was rather steady during decomposition, although small increases were observed at the beginning. At the end of the study the loss of $\mathrm{Mg}$ from the residues represented $56 \%$ of the initial content. This result is coincident with other studies related to litter and harvest residue decomposition, which highlight the higher mobility of $\mathrm{Mg}$ in residues, compared with Ca (Ganjegunte et al., 2004; Shortle et al., 2012). It has been frequently reported that the release of $\mathrm{Mg}$ follows biomass decomposition patterns (Costa et al., 2005; Hernández et al., 2009), however, this was only partially supported by this work. In our study nearly half the initial $\mathrm{Mg}$ remained in the less decomposed woody fractions, in contrast with a small proportion accounted for in needles, but overall, a higher proportion of $\mathrm{Mg}$ was lost from residues, compared to biomass.

\subsection{Conclusion}

Although nutrient export with $P$. taeda logs was substantial, the majority of $\mathrm{K}$, $\mathrm{Ca}, \mathrm{Mg}, \mathrm{N}$ and $\mathrm{P}$ remained in forest residues. Nevertheless, given the natural low fertility of the soils, nutrient export should be taken into consideration to assess the sustainability of this production system in the long-term.

In general, residue decomposition patterns were in line with previous works, especially regarding faster decomposition of needles compared to woody fractions. However, some seasonal and between fractions differences, e.g. the initial high decomposition rate of branches, could not be fully explained by the examined residue quality and climatic factors.

While the fast loss of $\mathrm{K}$ from the residues suggests that it did not depend on biomass decay, the increasing concentration, and slow release of the other studied nutrients following decomposition, indicate that the process could have been delayed by nutrient scarcity.

\section{Acknowledgements}

This study was funded by CSIC (Comisión Sectorial de Investigación Científica) of the Universidad de la República Oriental del Uruguay, COFUSA, FIMNSA, Montes del Plata, UPM and Weyerhaeuser. We would like to thank the technical staff of FIMNSA for providing the logistical support for field evaluations. We also sincerely acknowledge Magdalena Peluffo for the technical assistance.

\section{Conflicts of Interest}

The authors declare no conflicts of interest regarding the publication of this paper. 


\section{References}

Alvarez, E., Fernández Marcos, M. L., Torrado, V., \& Fernández Sanjurjo, M. J. (2008). Dynamics of Macronutrients during the First Stages of Litter Decomposition from Forest Species in a Temperate Area (Galicia, NW Spain). Nutrient Cycling in Agroecosystems, 80, 243-256. https://doi.org/10.1007/s10705-007-9140-4

Austin, A. T., \& Vivanco, L. (2006). Plant Litter Decomposition in a Semi-Arid Ecosystem Controlled by Photodegradation. Nature, 442, 555-558.

https://doi.org/10.1038/nature05038

Bani, A., Pioli, S., Ventura, M., Panzacchi, P., Borruso, L., Tognetti, R., Tonon, G., \& Brusetti, L. (2018). The Role of Microbial Community in the Decomposition of Leaf Litter and Deadwood. Applied Soil Ecology, 126, 75-84.

https://doi.org/10.1016/j.apsoil.2018.02.017

Berg, B., \& McClaugherty, C. (1989). Nitrogen and Phosphorus Release from Decomposing Litter in Relation to the Disappearance of Lignin. Canadian Journal of Botany, 67, 1148-1156. https://doi.org/10.1139/b89-150

Blumfield, T. J., \& Xu, Z. H. (2003). Impact of Harvest Residues on Mineral Nitrogen Dynamics Following Clearfall Harvesting of a Hoop Pine Plantation in Subtropical Australia. Forest Ecology and Management, 179, 55-67. https://doi.org/10.1016/S0378-1127(02)00485-1

Bowman, W. D., Steltzer, H., Rosentiel, T. N., Cleveland, C. C., \& Meier, C. L. (2004). Litter Effects of Two Co-Occurring Alpine Species on Plant Growth, Microbial Activity and Immobilization of Nitrogen. Oikos, 104, 336-344.

https://doi.org/10.1111/j.0030-1299.2004.12721.x

Bravo-Oviedo, A., Ruiz-Peinado, R., Onrubia, R., \& del Río, M. (2017). Thinning Alters the Early-Decomposition Rate and Nutrient Immobilization-Release Pattern of Foliar Litter in Mediterranean Oak-Pine Mixed Stands. Forest Ecology and Management, 391, 309-320. https://doi.org/10.1016/j.foreco.2017.02.032

Bremner, J. M., \& Mulvaney, C. S. (1982). Nitrogen-Total. In Methods of Soil Analysis. Part 2. Chemical and Microbiological Properties (595-624). Madison, WI: ASA and SSSA.

Corbeels, M., O’Connell, A. M., Grove, T. S., Mendham, D. S., \& Rance, S. J. (2003). Nitrogen Release from Eucalypt Leaves and Legume Residues as Influenced by Their Biochemical Quality and Degree of Contact with Soil. Plant and Soil, 250, 15-28. https://doi.org/10.1023/A:1022899212115

Costa, G. S., da Gama Rodrigues, C., \& de Melo Cunha, G. (2005). Decomposiçäo e liberaçäo de nutrientes da serapilheira foliar em povoamentos de Eucalyptus grandis no Norte Fluminense. Revista Arbore, 29, 563-570. https://doi.org/10.1590/S0100-67622005000400008

Dalias, P., Anderson, J. M., Bottner, P., \& Couteaux, M. M. (2001). Temperature Responses of Carbon Mineralization in Conifer Forest Soils from Different Regional Climates Incubated under Standard Laboratory Conditions. Global Change Biology, 6, 181-192. https://doi.org/10.1046/j.1365-2486.2001.00386.x

Durán, A., \& García Préchac, F. (2009). Soils of Uruguay. Vol. 1 Environmental Factors, Classification and Characterization. Montevideo: Hemisferio Sur.

Ganjegunte, G. K., Condron, L. M., Clinton, P. W., Davis, M. R., \& Mahieu, N. (2004). Decomposition and Nutrient Release from Radiata Pine (Pinus radiata) Coarse Woody Debris. Forest Ecology and Management, 187, 197-211.

https://doi.org/10.1016/S0378-1127(03)00332-3 
Garret, L., Davis, M., \& Graeme, O. (2007). Decomposition of Coarse Debris, and Methods for Determining Decay Rates. New Zealand Journal of Forestry Science, 37, 227-240.

Ghaffariyan, M. R., \& Apolit, R. (2015). Harvest Residues Assessment in Pine Plantations Harvested by Whole Tree and Cut-to-Length Harvesting Methods (a Case Study in Queensland, Australia). Silva Balcanica, 16, 113-122.

Girisha, G. K., Condron, L. M., Clinton, P. W., \& Davis, M. R. (2003). Decomposition and Nutrient Dynamics of Green and Freshly Fallen Radiata Pine (Pinus radiata) Needles. Forest Ecology and Management, 179, 169-181. https://doi.org/10.1016/S0378-1127(02)00518-2

Goma-Tchimbakala, J., \& Bernhard-Reversat, F. (2006). Comparison of Litter Dynamics in Three Plantations of an Indigenous Timber-Tree Species (Termicalia superba) and a Natural Tropical Forest in Mayombe, Congo. Forest Ecology and Management, 229, 304-313. https://doi.org/10.1016/j.foreco.2006.04.009

González, A., Hernández, J., \& del Pino, A. (2016). Nutritious Elements Extraction and Recycling at Harvest of Eucalyptus globulus in Uruguay. Bosque, 37, 175-186. https://doi.org/10.4067/S0717-92002016000100017

Goya, J. F., Pérez, C., Frangi, J. L., \& Fernández, R. (2003). Harvest Effect and Residue Fate on Nutrient Stability of Pinus taeda L. Plantations. Ecología Austral, 13, 139-150.

Hernández, J., del Pino, A., Hitta, M., \& Lorenzo, M. (2016). Management of Forest Harvest Residues Affects Soil Nutrient Availability during Reforestation of Eucalyptus grandis. Nutrient Cycling in Agroecosystems, 105, 141-155. https://doi.org/10.1007/s10705-016-9781-2

Hernández, J., del Pino, A., Salvo, S., \& Arrarte, G. (2009). Nutrient Export and Harvest Residue Decomposition Patterns of a Eucalyptus dunnii Maiden Plantation in Temperate Climate of Uruguay. Forest Ecology and Management, 258, 92-99.

https://doi.org/10.1016/j.foreco.2009.03.050

INUMET (2020).

http://inumet.gub.uy/clima/estadísticas-climatologicas/tablas-estadísticas

Isaac, R. A., \& Kerber, J. D. (1971). Atomic Absorption and Flame Photometry: Techniques and Uses in Soil, Plant and Water Analysis. In Instrumental Methods for Analysis of Soil and Plant Tissues (pp. 17-37). Madison, WI: SSSA.

https://doi.org/10.2136/1971.instrumentalmethods.c2

Jacob, M., Weland, N., Platner, C., Schaefer, M., Leuschner, C., \& Thomas, F. M. (2009). Nutrient Release from Decomposing Leaf Litter of Temperate Deciduous Forest Trees along a Gradient of Increasing Tree Species Diversity. Soil Biology and Biochemistry, 41, 2122-2130. https://doi.org/10.1016/j.soilbio.2009.07.024

Jobbagy, E. G., \& Jackson, R. B. (2003). Patterns and Mechanisms of Soil Acidification in the Conversion of Grasslands to Forests. Biogeochemistry, 54, 205-229. https://doi.org/10.1023/A:1024985629259

Jones, H. E., Madeira, M., Herraez, L., Dighton, J., Fabiâo, A., González-Rio, F., Fernández Marcos, M., Gomez, C., Tomé, M., Feith, H., Magalhâes, M. C., \& Howson, G. (1999). The Effect of Organic-Matter Management on the Productivity of Eucalyptus globulus Stands in Spain and Portugal: Tree Growth and Harvest Residue Decomposition in Relation to Site and Treatment. Forest Ecology and Management, 122, 73-86. https://doi.org/10.1016/S0378-1127(99)00033-X

Kraus, T., Dahlgren, R. A., \& Zasoski, R. J. (2003). Tannins in Nutrient Dynamics of Forest Ecosystems-A Review. Plant and Soil, 256, 41-66.

https://doi.org/10.1023/A:1026206511084

Laclau, J. P., Bouillet, J. P., \& Ranger, J. (2000). Dynamics of Biomass and Nutrient Ac- 
cumulation in a Clonal Plantation of Eucalyptus in Congo. Forest Ecology and Management, 128, 181-196. https://doi.org/10.1016/S0378-1127(99)00146-2

Mavimbela, L. Z., Crous, J. W., Morris, A. R., \& Chirwa, P. W. (2018). The Importance of Harvest Residue and Fertiliser on Productivity of Pinus patula across Various Sites in Their First, Second and Third Rotations, at Usutu Swaziland. New Zealand Journal of Forestry Science, 48, 5. https://doi.org/10.1186/s40490-018-0110-1

McTiernan, K. B., Coûteaux, M. M., Berg, B., Berg, M. P., de Anta, R. C., Gallardo, A., Kratz, W., Piussi, P., Remacle, J., \& De Santo, A. V. (2003). Changes in Chemical Composition of Pinus sylvestris Needle Litter during Decomposition along a European Coniferous Forest Climatic Transect. Soil Biology and Biochemistry, 35, 801-812. https://doi.org/10.1016/S0038-0717(03)00107-X

Murphy, J., \& Riley, J. P. (1962). A Modified Single Solution Method for the Determination of Phosphate in Natural Waters. Analytica Chimica Acta, 27, 31-36. https://doi.org/10.1016/S0003-2670(00)88444-5

Nelson, D. W., \& Sommers, L. E. (1996). Total Carbon, Organic Carbon, and Organic Matter. In D. L. Sparks et al. (Eds.), Methods of Soil Analysis. Part 3. Chemical Methods (pp. 961-1010). Madison WI: ASA and SSSA. https://doi.org/10.2136/sssabookser5.3.c34

Ouro, G., Pérez-Batallón, P., \& Merino, A., (2001). Effects of Sylvicultural Practices on Nutrient Status in a Pinus radiata Plantation: Nutrient Export by Tree Removal and Nutrient Dynamics in Decomposing Logging Residues. Annals of Forest Science, 58, 411-422. https://doi.org/10.1051/forest:2001134

Palviainen, M., Finér, L., Kurka, A. M., Mannerkoski, H., Piirainen, S., \& Starr, M. (2004). Release of Potassium, Calcium, Iron and Aluminium from Norway Spruce, Scots Pine and Silver Birch Logging Residues. Plant and Soil, 259, 123-136.

https://doi.org/10.1023/B:PLSO.0000020938.78215.bd

Parfitt, R. L, Percival, H. J., Dahlgren, R. A., \& Hill, L. F. (1997). Soil and Solution Chemistry under Pasture and Radiata Pine in New Zealand. Plant and Soil, 191, 279-290. https://doi.org/10.1023/A:1004266000509

Pérez-Batallón, P., Ouro, G., Macías, F., \& Merino, A. (2001). Initial Mineralization of Organic Matter in a Forest Plantation Soil Following Different Logging Residue Management Techniques. Annals of Forest Science, 58, 807-818. https://doi.org/10.1051/forest:2001164

Pettersen, R. C. (1984). The Chemical Composition of Wood. The Chemistry of Solid Wood. In Advances in Chemistry Series (Book 207) (57-126). Washington DC: American Chemical Society. https://doi.org/10.1021/ba-1984-0207.ch002

Prescott, C. E. (2005). Do Rates of Litter Decomposition Tell Us Anything We Really Need to Know? Forest Ecology and Management, 220, 66-74. https://doi.org/10.1016/j.foreco.2005.08.005

Ruiz-Peinado, R., Bravo-Oviedo, A., López-Senespleda, G., Montero, G., \& Río, M. (2013). Do Thinnings Influence Biomass and Soil Carbon Stocks in Mediterranean Maritime Pinewoods? European Journal of Forest Research, 32, 253-262.

https://doi.org/10.1007/s10342-012-0672-Z

SAS Institute Inc., Cary, NC, USA (2011). The Statistic Program.

Segura, C., Fernández-Ondoño, F., Jiménez, M. N., \& Navarro, F. B. (2017). Thinning Affects the Needle Fall Nutrient Return to Soil in a Semiarid Aleppo pine Afforestation While the Nutrient Dynamics Remain Unchanged. Forest Ecology and Management, 405, 257-270. https://doi.org/10.1016/j.foreco.2017.09.049

Shorohova, E., Kapitsa, E., Kazartsev, I., Romashkin, I., Polevoi, A., \& Kushnevskaya, H. 
(2016). Tree Species Traits Are the Predominant Control on the Decomposition Rate of Tree Log Bark in a Mesic Old-Growth Boreal Forest. Forest Ecology and Management, 377, 36-45. https://doi.org/10.1016/j.foreco.2016.06.036

Shortle, W. C., Smith, K. T., Jellison, J., \& Schilling, J. S. (2012). Potential of Decaying Wood to Restore Root-Available Base Cations in Depleted Forest Soils. Canadian Journal of Forest Research, 42, 1015-1024. https://doi.org/10.1139/x2012-056

Singleton, V. L., \& Rossi, J. A. (1965). Colorimetry of Total Phenolics with Phosphomolybdic-Phosphotungstic Acid Reagents. American Journal of Enology and Viticulture, 16, 144-158.

Soil Survey Staff (2006). Keys to Soil Taxonomy (10th ed.). Washington DC: United States Department of Agriculture, Natural Resources Conservation Service.

Turner, J., \& Lambert, M. (2013). Analysing Inter-Rotational Productivity and Nutrition in a New South Wales Radiata Pine Plantation. New Forests, 44, 785-798. https://doi.org/10.1007/s11056-013-9369-5

Tutua, S. S., Xu, Z. H., Blumfiel, T. J., \& Bubb, K. A. (2008). Long-Term Impacts of Harvest Residue Management on Nutrition, Growth and Productivity of an Exotic Pine Plantation of Sub-Tropical Australia. Forest Ecology and Management, 256, 741-748. https://doi.org/10.1016/j.foreco.2008.05.029

Vávřová, P., Penttilä, T., \& Laiho, R. (2009). Decomposition of Scots Pine Fine Woody Debris in Boreal Conditions: Implications for Estimating Carbon Pools and Fluxes. Forest Ecology and Management, 257, 401-412.

https://doi.org/10.1016/j.foreco.2008.09.017

Węgiel, A., Małek, S., Bielinis, E., Grebner, D. L., Polowy, K., \& Skonieczna, J. (2018). Determination of Elements Removal in Different Harvesting Scenarios of Scots Pine (Pinus sylvestris L.) Stands. Scandinavian Journal of Forest Research, 33, 261-270. https://doi.org/10.1080/02827581.2017.1352019

Wu, C., Zhang, Z., Wang, H., Li, C., Mo, Q., \& Liu, Y. (2018). Photodegradation Accelerates Coarse Woody Debris Decomposition in Subtropical Chinese Forests. Forest Ecology and Management, 409, 225-232. https://doi.org/10.1016/j.foreco.2017.10.060 